This article was downloaded by: [universidad miguel hernandez]

On: 8 April 2009

Access details: Access Details: [subscription number 778411047]

Publisher Routledge

Informa Ltd Registered in England and Wales Registered Number: 1072954 Registered office: Mortimer House, 37-41 Mortimer Street, London W1T 3JH, UK

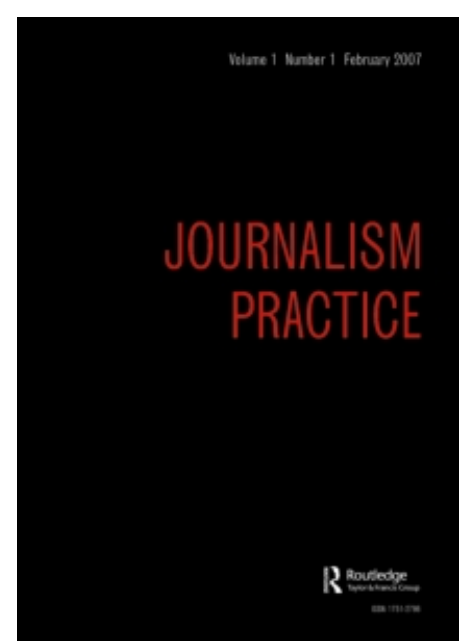

\title{
Journalism Practice
}

Publication details, including instructions for authors and subscription information:

http://www.informaworld.com/smpp/title content=t762290976

\section{NEWSROOM INTEGRATION IN AUSTRIA, SPAIN AND GERMANY}

José García Avilés; Klaus Meier; Andy Kaltenbrunner; Miguel Carvajal; Daniela Kraus

First Published on: 25 March 2009

To cite this Article Avilés, José García, Meier, Klaus, Kaltenbrunner, Andy, Carvajal, Miguel and Kraus, Daniela(2009)'NEWSROOM INTEGRATION IN AUSTRIA, SPAIN AND GERMANY',Journalism Practice,

To link to this Article: DOI: $10.1080 / 17512780902798638$

URL: http://dx.doi.org/10.1080/17512780902798638

\section{PLEASE SCROLL DOWN FOR ARTICLE}

Full terms and conditions of use: http://www.informaworld.com/terms-and-conditions-of-access.pdf

This article may be used for research, teaching and private study purposes. Any substantial or systematic reproduction, re-distribution, re-selling, loan or sub-licensing, systematic supply or distribution in any form to anyone is expressly forbidden.

The publisher does not give any warranty express or implied or make any representation that the contents will be complete or accurate or up to date. The accuracy of any instructions, formulae and drug doses should be independently verified with primary sources. The publisher shall not be liable for any loss, actions, claims, proceedings, demand or costs or damages whatsoever or howsoever caused arising directly or indirectly in connection with or arising out of the use of this material. 


\title{
NEWSROOM INTEGRATION IN AUSTRIA, SPAIN AND GERMANY \\ Models of media convergence
}

\author{
José A. García Avilés, Klaus Meier, Andy Kaltenbrunner, \\ Miguel Carvajal, and Daniela Kraus
}

\begin{abstract}
Convergence is reshaping the landscape of journalism in a variety of ways. This comparative study was targeted on integrated newsrooms, which combine at least two platforms: print and online, in some cases also television and radio. Research was conducted in six media companies which are undergoing some degree of newsroom convergence in Austria, Spain and Germany. Descriptors for different levels of cross-media production and the process of convergence were established - avoiding technological determinism and the typical mindset in the industry that regards full integration as the necessary final step of any convergence project. As a result of the transnational comparison of six case studies, a convergence matrix for analysis and comparison of integrated newsrooms was outlined. The matrix is related to four essential areas of development in a media convergence process: project scope, newsroom management, journalistic practices, work organization. Based on this matrix, three models of newsroom convergence were drawn: full integration, cross-media and co-ordination of isolated platforms.
\end{abstract}

KEYWORDS European media; journalism; media convergence; multimedia; newsroom integration

\section{Introduction}

Over the last few years, many media companies in Europe and other parts of the world have implemented convergence processes that raise fundamental questions about the future of journalism (Lawson-Borders, 2006; Saltzis and Dickinson, 2008; Singer, 2004). Media convergence is inseparably related to industry convergence; the communications, computer and media sectors found a common path, facilitated by the deregulation of communications law, media digitalization and the global reach of the Internet (Bauer, 2005). As the businesses of content providers and distributors moved closer together, the media companies positioned themselves strategically within the new scenario, forging alliances with partners from other sectors (Chan-Olmsted and Chang, 2003). In this way, the process of fusions, mergers and acquisitions of traditional- and new-media companies accelerated the transition to the new converged era, one in which cross-ownership and business economics shape market structure.

Convergence refers to "some combination of technologies, products, staffs and geography amongst the previously distinct provinces of print, television and online 
media" (Singer, 2004, p. 3). The phenomenon can be analysed from at least four perspectives: technological, managerial, communicative and professional, all of which are intertwined in a continuously changing media environment (García Avilés, 2006). Convergence is reshaping the landscape of journalism in a variety of ways for, as Pavlik puts it: "newsroom structures, journalistic practices and news content are all evolving" (2004, p. 28). The process has been described "in terms of (increasing) cooperation and collaboration between formerly distinct media newsrooms and other parts of the modern media company" (Deuze, 2004, p. 140).

According to Quinn (2005), managers adopt convergence with two, not necessarily opposing, main goals in mind: improving the quality of journalism and tightening production costs. From management's point of view, the most frequent strategies are collaboration and partnership among the different media. Thus, managers have used convergence in order to achieve more efficient multiplatform news production and improve performance. Convergence is usually a corporate management decision when it involves several business units, such as organisational structure, production, distribution, marketing and human resources (Killebrew, 2005).

Professional convergence is the main focus of our study. From the journalistic perspective, convergence and newsroom integration generate fundamental changes in news production and organization. Digital systems allow journalists to share data (audio, video and text) in order to elaborate content for the various platforms with increasing versatility. At integrated newsrooms, multi-skilled journalists produce news for at least two platforms: print, radio, television, mobile devices and the Internet. This varied work for several platforms may lead to more creative journalistic story-telling but also to a growing pressure on editors and reporters (Meier, 2009).

Dailey et al. (2005) conceptualize the nature of newsroom convergence according to the assumption of evolving degrees of interaction and co-operation among cross-media partners and whether the media are owned by common or separate companies. These authors establish a standard of measurement - "the Convergence Continuum Model" - and offer operational definitions of the various levels in that model. Within this framework, news convergence is defined as a series of behaviour-based activities illustrating the interaction and co-operation stages of staff at newspapers, television stations and online organizations. The dynamic continuum's components provide media professionals with a better understanding of an evolutionary trend in their industry as they develop cross-media alliances. Each of those levels comprises a series of tasks and processes. At the basic level, each medium gathers, packages and delivers the news on its own and uses cross-promotion on other platforms; at the top level, a single newsroom generates content for several platforms.

Much of the literature argues that convergence is reshaping the fundamental relationships between journalists, their sources and their audiences (Boczkowski and Ferris, 2005; Lawson-Borders, 2006). A broadened research basis is therefore needed in order to align existing data with a supporting context in different countries. Our comparative study has been strongly influenced by the idea of finding descriptors for different levels of crossmedia production and the process of convergence. Results were tabulated and a convergence matrix was outlined as the basis of a model for the classification of converging newsrooms. The continuum model suggests a step-by-step development of increasing levels in order to reach a higher degree of convergence. Our matrix intends to analyse the state of newsroom integration without automatically favouring one level over another. 


\section{Methodology}

In a world of globalising media markets, knowledge about convergence development and insights into how to foster quality journalism in this context can best be gained with an international perspective. Comparative work is difficult (Esser and Pfetsch, 2004), which is perhaps why comparative media research is relatively thin on the ground. It requires deep knowledge of the phenomena being examined as well as methods that allow meaningful equivalences which, at the same time, do not neglect the wealth of different meanings that exist in diverse cultural contexts. Our research focuses on professional attitudes and practices in six media organizations undergoing some kind of newsroom convergence in Austria, Germany and Spain. The case study method was chosen as the most appropriate for analysing convergence, since it is acknowledged as a valid tool for analysing a complex issue and permitting research of a phenomenon in its own context (Stake, 1995). Such a qualitative method relies on sources such as direct observation, interviews, written records and other documents to validate its conclusions. Case studies have frequently been used as a methodological tool to examine the implications of newsroom convergence (Dupagne and Garrison, 2006; García Avilés and Carvajal, 2008; Huang et al., 2006).

Two case studies were conducted in each country in order to determine the type of convergence strategies that were being implemented. The decisive factor when selecting the three countries and the six cases was that of gathering a variety of convergence preconditions (e.g. the country's media policy, the degree of media concentration, the size of the markets and regional traditions of media culture). In order not to over-extend the study and to allow a focused point of view, we concentrated on media organizations with a daily print newspaper as the traditional core product. The results are based on newsroom observation and interviews with 28 news managers and journalists in those media analysed. ${ }^{1}$ The initial hypothesis was that several models of newsroom convergence might be established according to various descriptors which influence the production of news. Media convergence cases were analysed and compared by using the following four core research questions:

- Are there different types of newsroom convergence in each country or even in each case?

- How do newsrooms organize the editorial workflow between the various platforms?

- What is the influence of convergent newsroom structures on the job satisfaction of journalists?

- What are the levels of multiskilling at each media company?

\section{National Media Context and Comparative Analysis}

Convergence development is dependent not only on the economic and strategic interests of publishers and broadcasters but also on the influence of national parameters. To be able to conduct this international study, each country's market was analysed. A thorough and extensive commentary of this comparison, however, goes beyond the limits of this article.

According to 2005 country data (Oficina de Control de la Difusión (OJD) and World Association of Newspapers (WAN)), the readership index in Austria was 266 sold copies per 1000 inhabitants, followed by Germany (261) and Spain (98). Although German newspaper 
publishers became involved in the Internet in the mid-1990s (Neuberger and Tonnemacher, 2003), in most cases they did so hesitantly and with scant resources (Meyer, 2005). However, the trend towards cross-media newsrooms has also been gaining momentum in Germany since 2006 (Meier, 2007, 2009). In Austria, newspapers' online editions were developed in 1995 and 1996 (e.g. Der Standard, Kurier, Vorarlberger Medienhaus). Another relevant difference in national standards is that the convergence process in Central Europe is clearly more Web-driven than in Spain, due to higher Internet penetration and faster broadband development in Germany and Austria.

The importance of the radio and television markets in Spain, by contrast, is based on the early opening of these markets with only a few limitations to cross-ownership. This gives more relevance to cross-media strategies both at the national and regional levels, as well as some degree of media company concentration which is not legally permitted in Germany and Austria. The penetration of free daily newspapers is also relevant since, while there is no free newspaper market in Germany to date, Spanish free newspapers are already very successful as a new competitor and in Austria two papers of this kind have been launched at local level.

\section{Case Studies}

\section{Austria}

In Austria - due to the restrictions in media company cross-ownership and the late opening of the private radio and TV markets - newspapers' convergence strategies are mainly focused on the production of multimedia content in new, planned newsroom environments (Kaltenbrunner et al., 2007; Steinmaurer, 2002). Two case studies were selected: (1) the very new newsroom of Österreich/OE24.at, the daily newspaper and multimedia production founded in Vienna in September 2006 and (2) Der Standard, whose online edition (derstandard.at) is one of the most successful Austrian platforms with a national market share of 14.9 per cent in 2007.

Newsroom convergence at Österreich. In September 2006, the daily newspaper Österreich was launched by Wolfgang Fellner, who had previously been successful in the magazine market as founder of the "News" magazine group. Marketing for the new paper included the announcement of a "dialogue between print and online". Its multimedia production occupies a 2400 square metre newsroom with state of the art technology, where 150 professionals produce both the print and online editions. According to the data of the independent "Österreichische Auflagenkontrolle" (ÖAK), Österreich reached a circulation of 310,000 in 2007 , of which 167,000 were sold copies. Nearly 50 per cent were free copies, given away mainly in subway stations. Österreich was designed as a convergent product from the start. Nevertheless, its online edition is a separate legal unit with a slightly different ownership structure. The newsroom displays a circular architecture where sections are situated around the inner circle, the so-called "Tower of Power" with the editors-in-chief's desks. The concept was designed to integrate online and print journalists in each section but did not work. About 15 online journalists are now located in their own section. "We want co-operation and co-ordination but prefer to have experts in each platform", the general manager said. Each of them faces a large screen on which the production of the print pages can be observed. In this way, the online team knows exactly what is being discussed in print although both platforms are organized separately. 
The morning conference is attended by editors from both the print and online teams. The online team announces its main topics for the day at this conference, as does every other section. It is there that decisions on thematic co-ordination and cross-media marketing are made.

Although "online first" has been announced as a policy, the Web has not been given priority in publishing scoops. If print has an exclusive story, a teaser will be published online shortly before the story is announced via news agencies, but not the full-length story. There are two different Content Management Systems for print and online.

The concept of architectural integration aims to foster internal communication, although everybody is responsible for news production on his or her own platform. The level of multiskilling is not very high in the Österreich newsroom. Some video specialists work in the online section. The newspaper co-operated with a local broadcaster to produce hourly television news broadcast on the Web but it turned out to be too expensive.

Newsroom convergence at Der Standard. Der Standard launched its Web edition derstandard.at in 1995 as the first German-language online newspaper. The Web edition reaches a higher number of users (1.2 million monthly unique users) than the quality newspaper (341,000 daily readers). The derstandard.at company became an autonomous legal unit in 2000; it is now 100 per cent owned by its founder and publisher Oscar Bronner. Since 2004, derstandard.at has been one of the very few European online operations of print origin which has reported revenues.

The relation between derstandard.at and Der Standard is an example of success without any integration. Its online journalists are convinced that their success partly comes from their newsroom independence. "Our own newsroom reputation grew a lot during the first years and now we have reached the same level as the print newsroom", the derstandard.at's chief-editor said. Traditionally, there has not been any convergence at all between Der Standard and derstandard.at. Both newsrooms are located in separate buildings in Vienna's historic city centre and the construction of a modern, integrated newsroom was not possible.

Derstandard.at's newsroom, with 50 journalists, is the largest online newsroom in Austria. The online edition publishes all of the newspaper's stories, but only after they have appeared in print. The online company pays for this content. "Online first" was discussed but not considered a good strategy by print management. Nevertheless, some steps have already been undertaken to build a stronger connection. Since autumn 2007, the online co-ordinator has attended the morning print conference and co-ordination meetings are held on a regular basis.

Bi-medial work is carried out by a few journalists, such as the editor of the communication section, who is involved in cross-media reporting. However, it is not part of a management strategy but the result of the initiative of individual journalists.

\section{Spain}

The case studies in Spain were: (1) La Verdad Multimedia, which belongs to Vocento, the first Spanish media group that adopted a regional multimedia strategy as its core business in 2001. The company owns 12 regional multimedia companies that comprise a newspaper, its online edition, a local radio station, a local television channel and an 
advertising agency and (2) the national newspaper El Mundo, owned by Unidad Editorial Group, that is currently implementing a process of newsroom convergence.

Newsroom convergence at El Mundo. El Mundo is a newspaper which launched in 1989 and which had a circulation of 337,000 in 2007 (OJD's audit bureau); its Web edition Elmundo.es is Spain's online market leader, with over 11.6 million unique users per month. The company is owned by the Italian group RCS Rizzoli. In February 2007, Rizzoli bought the successful Recoletos Multimedia Group which publishes the leading sports daily Marca, the leading business daily Expansión and several specialized magazines. The new multimedia group, known as Unidad Editorial, moved to a new building in the north of Madrid in December 2007, an 18,000 square metre facility which houses one of Europe's largest newsrooms, along with 350 El Mundo, 100 Expansión and 250 Marca journalists. According to management, about 300 jobs from the administrative and commercial departments were shed as a result of the merger.

El Mundo's newsroom initiated a move towards integration in July 2007. The move from a multi-storey building to the biggest open plan, single-level office space in Madrid was a "crucial change", according to the El Mundo's assistant editor. He said that although staff began the move with reluctance, after the first few weeks they began to appreciate a variety of things they could do with greater ease in an integrated newsroom.

In July 2007, print and online journalists from four sections (Communication, Science, Info-graphics and Sports) moved in together in order to produce content across media boundaries. After several months of integration, news managers argue that it has been a valuable experience and that they plan to gradually expand the initiative to other sections. The editor of the Communication section emphasized how much overlap there is between each of these integrated teams, where reporters and production staff sit side-by-side and produce stories both for print and online. "Curiosity and looking over each others' shoulders are the order of the day", she said.

Besides the physical movement of print desks alongside online desks, El Mundo's newsroom integration is blurring the lines between print and multimedia operations, since newspaper journalists are expected to work on online projects and new-media reporters to work in print (although the move is mainly from print to online). A growing expectation that journalists will collect information in multiple formats has been generated, with some controversy. Most journalists, particularly print ones, are not exactly eager to learn how to become multimedia storytellers. Although staff began the move to the new facility with reluctance, after the first few weeks they began to appreciate a variety of things they could do with greater ease in an integrated newsroom. The news selection process has also changed. Supervising editors now rank stories, factoring importance and newsworthiness, but also "Web 2.0" considerations such as the popularity of a story or its coverage on other news sites.

El Mundo's assistant editor stressed the need for newspapers to integrate with caution: "If the goal is to create a stronger, more flexible organization, it only makes sense to move with some care and deliberation in bringing such disparate operations together". In fact, the integrated newsroom has not drastically changed the principles of the editorial process. Instead, integration has changed the way staffers think about the process and they are now learning to think in terms of the content rather than the medium (more precisely, in terms of content's suitability for a medium). 
Newsroom convergence in La Verdad Multimedia. La Verdad Multimedia is a regional group which publishes the newspaper La Verdad, the market leader in the South-Eastern Murcia region with a circulation of 39,000 according to the OJD audit bureau (2007). La Verdad started its online edition laverdad.es in 1998 and reaches a monthly average of 1.5 million unique users (OJD). The same company owns both local television (Punto TV) and radio (Punto Radio) stations, also as a part of the Vocento Media Group. The La Verdad Multimedia structure is designed to generate synergies between all of its outlets, especially in cross-promotion and content sharing. The group facilities are located in two separate buildings. A print newsroom for 95 journalists occupies the main building and is connected to a second building where 12 journalists in the audiovisual newsroom provide news to both the radio and television stations (Punto TV and Punto Radio).

Convergence is primarily developed at the newspaper website, which publishes news and features from the print edition and a selection of audiovisual news stories. The newspaper editor points out that "management does not demand work for more than one platform but journalists know some contributions to other media are expected". However, when a deadline is approaching and time is limited, they have "to focus on their primary medium".

When managers launched both radio and television stations in 2004 they created the role of "multimedia co-ordinator" in order to foster content sharing and common strategies among the different newsrooms. This co-ordination never crosses the point of having journalists of one medium working for another one; the newsrooms remain completely independent but La Verdad's news flow allows for each media outlet to share information gathered by its cross-media partner and to publish it after repackaging by journalists. Partners might also share news budgets or attend each other's planning sessions. News directors from print, online and audiovisual meet regularly to exchange ideas, provide each other with feedback, share material from the stories they have covered, plan longer investigative pieces together and share the cost for special projects. As La Verdad's editor-in-chief pointed out: "convergence is mainly developed at editor level; editors and section editors are the most committed to multimedia collaboration".

\section{Germany}

In a preliminary study in Germany, the convergence situation in general and five cross-media newsrooms were analysed (Meier, 2009; Schantin et al., 2007). For purposes of international comparison, two cases - one national and another regional-have been selected: the Die Welt/Morgenpost-group and Hessische-Niedersächsische Allgemeine (HNA).

Newsroom convergence at the Die Welt/Morgenpost-group. In November 2006, the Welt/Morgenpost-group in Berlin opened a joint newsroom for three daily papers (Die Welt, Welt Kompakt and Berliner Morgenpost), a Sunday paper (Welt am Sonntag) and the associated online versions. The challenge lies not only in combining print and Web operations, but also in integrating the various print titles, which must still retain their own profile. Some 400 journalists - including 38 online professionals - work for the Welt/ Morgenpost-group. This is the biggest convergence project at a German newspaper publishing house. The sold circulation figures of the print titles - going against the industry trend-increased slightly in 2007 and the number of online users rose disproportionately. 
The Welt/Morgenpost group belongs to Axel Springer AG - the largest newspaper publishing house in Germany, with a 22.5 per cent newspaper market share.

The first step in the convergence process at the Welt/Morgenpost-group was the merging of the two newspaper newsrooms, Die Welt (national) and Berliner Morgenpost (regional), into a joint editorial team in 2002. Then, a new daily newspaper was launched in May 2004: Die Welt kompakt, a tabloid produced by the Welt/Morgenpost editorial teamin part with the same news material, but with a different concept for a younger target audience. The second step followed in November 2006, with the merging of this newsroom with the Sunday title Welt am Sonntag, whereas both online offerings, welt.de and morgenpost.de, assumed an "online first" policy.

Convergence led to savings and job cuts among the editorial staff (approximately 100 jobs in 2002 and 57 in 2006) although it was accompanied by an online expansion. Die Welt had never been profitable since its establishment in 1946 but was cross-financed for image reasons. After the merger, the implementation of newsroom convergence and the job cuts, the Welt/Morgenpost-group recorded a profit for the first time in 2007.

The Axel Springer building in Berlin has a 408-square-metre newsroom with 56 workplaces. Sitting at the "newsroom control unit" to co-ordinate coverage in the different platforms are the editors-in-chief, the managers of all of the platforms, the section heads and some politics, business and local-news editors - as well as about 20 online journalists. About 70 per cent of all journalists work across all of the platforms and 30 per cent are only involved with a single medium. The online department may use articles from all journalists as soon as they are finished. According to the online department director, "we can publish everything online - even exclusives. There is no longer any discussion about having to print exclusive stories first in the newspaper". The managing editor argues that they are trying to "gradually change the editorial organization and processes so that articles are written earlier on, when it is possible for online to make use of them, and not only when it is necessary for the newspaper. First and foremost, this means a different work organization as well as a heavier workload." Until now, there have been different employment contracts for print and online journalists. Online editors' salaries are lower than their print counterparts and the different types of contracts cause unrest among many staffers. More than 100 journalists have received training, especially on mindset and approaches to work on the Internet. The new Axel Springer Academy, established in January 2007, provides cross-media training. Print journalists are not forced to produce content for the Web although some of them have been experimenting with new formats, such as podcasting or blogging. The managing editor stresses that "working in a multimedia manner will only be successful if incentives, encouragement and backing are offered, opportunities highlighted, invitations issued, training organized and offers made".

Newsroom convergence at Hessische/Niedersächsische Allgemeine. Hessische/ Niedersächsische Allgemeine (HNA) in Kassel produces print and Web content in a joint office where the online team, the politics and business departments and the producing editors of the print edition work together. The video commitment of the editorial staff and innovative Web 2.0 formats such as a regional Wiki are some of HNA's highlights. The television programme Alszus is recorded daily in the local print editorial-office and is broadcast on the regional public channel. Currently, there are 140 print journalists and four online editors working for HNA. 
Cross-media co-operation between print and online has been an ongoing process since 2002. Four online editors are responsible for Web operations and print editors supply them with material. For several years the objective has been that every local editorial office should publish breaking news items on the Internet every day. Managers say that about 50 per cent of newspaper items - including all big stories - are published online.

The online department experimented with video on the Internet early in 2007. Reporters have started to shoot videos on location but they do not edit them: a small group of video editors is attached to the main office for this task.

Print and online journalists enjoy the same employment contracts and similar salaries. According to the chief editor, job satisfaction has increased, despite a heavier workload.

\section{Convergence Descriptors: Towards a Matrix Model}

In order to compare the six case studies, a matrix of 32 convergence descriptors was developed. These descriptors were outlined following interviews and newsroom observations, in order to answer the most important research questions initially formulated. The descriptors are related to four essential areas of development in a media convergence process:

1. Project scope.

2. Newsroom management.

3. Journalistic practices.

4. Work organization.

Project scope has to do with developing a common understanding as to what is included in a specific project, which allows calculating its cost and time frame as well as where project responsibilities begin and end. This area deals with the extent of the convergence strategy; it might involve the whole company or it might just be centred on collaboration among newsrooms. In our study, four out of six organisations are developing both company and newsroom convergence (Table 1). Der Standard is not implementing any kind of convergence whereas La Verdad Multimedia is, so far, developing company convergence.

Convergence can also be regarded either as a goal or as a tool, to be implemented within a different time frame. Managers at the Welt/Morgenpost-group, HNA and EI Mundo regarded convergence as a company goal. At Der Standard there was no convergence strategy whereas at Österreich and La Verdad Multimedia, convergence is considered a tool. At HNA, La Verdad Multimedia and El Mundo, it is a long-term process, which will last for a number of years whereas at Österreich it is a short-term process. Managers at Welt/ Morgenpost specified that implementation of the cross-media newsroom was short-term but that convergence was a long-term process. We also enquired as to whether the approach to implementing the project was bottom-up or top-down. Convergence at Österreich only started in 2006. La Verdad Multimedia and El Mundo may be described as topdown projects. On the other hand, convergence implementation at HNA and the cooperation initiatives at Der Standard are being developed from the bottom up. Other questions in this area enquired about the level of internal communication: had the convergence strategy been openly discussed with journalists and had there been a newsroom "change management" programme which would allow for new informationprocessing strategies? Only in the German cases had there been open discussions with 
TABLE 1

Project scope

\begin{tabular}{|c|c|c|c|}
\hline & Full integration & Cross-media & $\begin{array}{l}\text { Co-ordination of } \\
\text { isolated platforms }\end{array}$ \\
\hline $\begin{array}{l}\text { Is it only company } \\
\text { convergence, just } \\
\text { newsroom or both? }\end{array}$ & $\begin{array}{l}\text { Both company and } \\
\text { newsroom convergence }\end{array}$ & $\begin{array}{l}\text { Company } \\
\text { convergence is an } \\
\text { option. Newsroom } \\
\text { convergence is an } \\
\text { option }\end{array}$ & $\begin{array}{l}\text { Company } \\
\text { convergence is } \\
\text { an option. } \\
\text { Newsroom } \\
\text { convergence does } \\
\text { not take place }\end{array}$ \\
\hline $\begin{array}{l}\text { Is convergence a } \\
\text { company goal or a tool? }\end{array}$ & $\begin{array}{l}\text { A company goal and an } \\
\text { overall strategy }\end{array}$ & A tool & Neither \\
\hline $\begin{array}{l}\text { Is convergence } \\
\text { considered a short-term } \\
\text { or a long-term process? }\end{array}$ & As a long-term process & $\begin{array}{l}\text { As a long-term } \\
\text { process in all the } \\
\text { sectors involved }\end{array}$ & $\begin{array}{l}\text { Company } \\
\text { convergence can } \\
\text { be a perspective- } \\
\text { without } \\
\text { precipitance }\end{array}$ \\
\hline $\begin{array}{l}\text { Is implementation } \\
\text { bottom-up or } \\
\text { top-down? }\end{array}$ & $\begin{array}{l}\text { Top-down, as convergence } \\
\text { is seen as an overall } \\
\text { strategy }\end{array}$ & $\begin{array}{l}\text { There is top-down } \\
\text { implementation of } \\
\text { convergence } \\
\text { processes as well } \\
\text { as bottom-up } \\
\text { initiatives }\end{array}$ & $\begin{array}{l}\text { If there is any, } \\
\text { bottom-up } \\
\text { development is } \\
\text { more probable }\end{array}$ \\
\hline $\begin{array}{l}\text { Has convergence strategy } \\
\text { been discussed with } \\
\text { journalists? Is there } \\
\text { newsroom "change } \\
\text { management"? }\end{array}$ & $\begin{array}{l}\text { Discussion of convergence } \\
\text { strategies with all employees } \\
\text { is part of the strategy; } \\
\text { change management is } \\
\text { implemented }\end{array}$ & $\begin{array}{l}\text { To a certain } \\
\text { extent; but not } \\
\text { all employees } \\
\text { are } \\
\text { involved }\end{array}$ & $\begin{array}{l}\text { Discussion only on } \\
\text { top level; no } \\
\text { change } \\
\text { management } \\
\text { necessary }\end{array}$ \\
\hline
\end{tabular}

journalists during the implementation of the convergence process and some organized change management attempted.

Newsroom management has a direct bearing on the medium's journalism practices and the quality of its output. The perceived atmosphere in a newsroom is related to the level of participation of reporters and whether managers attempt to give journalists information on the coming changes.

The first descriptor in this area relates to the priority of content over platform and to what extent the difference between newspaper journalists and Web journalists has diminished (Table 2). Managers at Österreich, Der Standard and La Verdad Multimedia agree that platform is still considered primary and content secondary, which means focusing on the success of different media within the group more than on the best ways of distributing the information-regardless of economic strategies. Content is primary, however, for management at both Welt/Morgenpost and El Mundo management whereas for management at HNA, both content and platform "are equally important". The existence of an "online first" policy was explicitly stated by both German media organizations, the Welt/ Morgenpost-group and HNA. News executives in the other media organisations say exclusives are held first for print, although this issue is often discussed by managers at La Verdad Multimedia.

News flow refers to the process leading from assignment and production to content packaging and distribution. News flow might be based around a central desk as at Welt/Morgenpost, around several multimedia editors as at El Mundo or on any other 
TABLE 2

Newsroom management

\begin{tabular}{|c|c|c|c|}
\hline & Full integration & Cross-media & $\begin{array}{l}\text { Co-ordination of } \\
\text { isolated platforms }\end{array}$ \\
\hline $\begin{array}{l}\text { Is content primary and } \\
\text { platform secondary, the } \\
\text { other way around or both } \\
\text { are equally important? }\end{array}$ & $\begin{array}{l}\text { Strategic distribution of } \\
\text { content is primary }\end{array}$ & $\begin{array}{l}\text { Platform is } \\
\text { primary; but } \\
\text { strategic } \\
\text { distribution of } \\
\text { content is equally } \\
\text { important }\end{array}$ & $\begin{array}{l}\text { Platform is } \\
\text { primary }\end{array}$ \\
\hline $\begin{array}{l}\text { Is there an "online first" } \\
\text { policy, are exclusives } \\
\text { held for print first or is } \\
\text { there no clear policy? }\end{array}$ & $\begin{array}{l}\text { Decisions on online first are } \\
\text { made according to strategic } \\
\text { principles }\end{array}$ & $\begin{array}{l}\text { Cross-media } \\
\text { managers decide } \\
\text { publication } \\
\text { strategies case by } \\
\text { case }\end{array}$ & $\begin{array}{l}\text { No online first } \\
\text { policy; platform } \\
\text { editors decide } \\
\text { autonomously }\end{array}$ \\
\hline $\begin{array}{l}\text { Is news flow based } \\
\text { around a central desk, } \\
\text { several editors or } \\
\text { another model? }\end{array}$ & $\begin{array}{l}\text { News flow is organized } \\
\text { around a central desk }\end{array}$ & $\begin{array}{l}\text { Two different desks } \\
\text { for print and online } \\
\text { that work together. } \\
\text { There is some sort } \\
\text { of permanent } \\
\text { co-ordination }\end{array}$ & $\begin{array}{l}\text { Several editors } \\
\text { with responsibility } \\
\text { for their platform }\end{array}$ \\
\hline $\begin{array}{l}\text { Newsroom management: } \\
\text { is there a single news } \\
\text { editor, multimedia } \\
\text { editors or another } \\
\text { model? }\end{array}$ & $\begin{array}{l}\text { Central news editor, who is } \\
\text { responsible for all platforms }\end{array}$ & $\begin{array}{l}\text { News editors for } \\
\text { each platform and } \\
\text { multimedia editors } \\
\text { for co-ordination }\end{array}$ & $\begin{array}{l}\text { News editors for } \\
\text { each platform }\end{array}$ \\
\hline $\begin{array}{l}\text { Are there editorial } \\
\text { meetings attended by } \\
\text { online, print and other } \\
\text { editors or do they hold } \\
\text { separate meetings? }\end{array}$ & $\begin{array}{l}\text { All editors and } \\
\text { section heads are } \\
\text { responsible for all platforms } \\
\text { in daily news production }\end{array}$ & $\begin{array}{l}\text { Editorial } \\
\text { conferences can be } \\
\text { attended by } \\
\text { journalists from all } \\
\text { platforms and must } \\
\text { be organized and } \\
\text { attended by } \\
\text { multimedia } \\
\text { co-ordinators }\end{array}$ & Separate meetings \\
\hline $\begin{array}{l}\text { Is journalists' } \\
\text { collaboration with } \\
\text { other platforms } \\
\text { encouraged? }\end{array}$ & Yes, as inherent to the system & $\begin{array}{l}\text { Partly_mainly } \\
\text { when multimedia } \\
\text { co-ordinators build } \\
\text { teams }\end{array}$ & $\begin{array}{l}\text { To a small extent. } \\
\text { Too much } \\
\text { crossover is } \\
\text { regarded as } \\
\text { problematic by } \\
\text { platform managers }\end{array}$ \\
\hline $\begin{array}{l}\text { Content management } \\
\text { systems: is there one } \\
\text { for all platforms or } \\
\text { different CMS for each? }\end{array}$ & One CMS & $\begin{array}{l}\text { One CMS is } \\
\text { possible but } \\
\text { different CMS are } \\
\text { usual as only } \\
\text { co-ordinators are } \\
\text { obliged to use all }\end{array}$ & $\begin{array}{l}\text { Different CMS as } \\
\text { there is no need } \\
\text { for permanent } \\
\text { exchange of news } \\
\text { and data }\end{array}$ \\
\hline
\end{tabular}

system. Der Standard's news flow is structured as two separate newsrooms with almost no interaction. Editorial meetings are attended by both online and print staff in all of the cases studied.

Journalistic convergence can also be analysed from the standpoint of the redefinition of professional practices. Firstly, researchers enquired as to whether a traditional division between news gathering, production and distribution existed (Table 3). All of 
TABLE 3

Journalistic practices

\section{Full integration}

Is there a division
between news
gathering,
production and
distribution?
Is technological
equipment for all
journalists a
precondition in news
gathering?
Is technological
equipment for all a
precondition in news
production?
Is technological
equipment for all a
precondition in news
distribution?
Is multiskilling a
precondition in news
gathering?

Division may be one strategy to gather materials and produce for all platforms

Yes, e.g. video-equipment in every section

Yes. All journalists may use all systems

Yes. Available for all_-but in everyday practice with specialists using it, e.g. for editing video-productions Yes, all journalists are encouraged to be multiskilled

Is multiskilling a Yes, at least as a strategic precondition in news goal production?

\section{Is multiskilling a Yes precondition in news distribution?}

Is working for several media platforms a precondition in news gathering?

Is working for several media platforms a precondition in news production?

Is working for several media platforms a precondition in news distribution?

Yes

\section{Cross-media}

Basically no, or not more than there has always been remains as it has always been

\section{No. Division}

To a certain extent, e.g. No video cameras in some sections

No. But platform co-ordinators do have all systems available. Some journalists will use them

No

No

To a certain extent. Multiskilled news gathering is encouraged as an option, never an obligation

No. Specialization in production is considered necessary to guarantee (technical) quality To a certain extent. For No some of the leading (co-ordinating) staff it is obligatory

To a certain extent.

Necessary for

platform

co-ordinators

No

No

There is always some specialization in production

To a certain extent. No
No

Co-ordination of isolated platforms 
TABLE 3 (Continued)

\begin{tabular}{lccc}
\hline & Full integration & Cross-media & $\begin{array}{c}\text { Co-ordination of } \\
\text { isolated platforms }\end{array}$ \\
$\begin{array}{l}\text { What percentage of } \\
\text { multi-skilled }\end{array}$ & $70-100$ & $20-70$ & $0-20$ \\
journalists work for & & \\
more than one & & Both \\
platform? & & Both \\
$\begin{array}{l}\text { Online video: is it } \\
\text { mostly produced }\end{array}$ & In-house & & \\
$\begin{array}{l}\text { in-house, mostly } \\
\text { externally } \\
\text { produced or both? }\end{array}$ & & \\
\hline
\end{tabular}

the media organizations had eliminated such divisions, with some minor exceptions at Welt/Morgenpost and El Mundo. Then, working practices were outlined according to different categories of preconditions during the different stages of the news-production process. Technological equipment was a precondition in news gathering in all media organizations except at Der Standard. Specifically, some print journalists are working with video cameras. However, it is never a precondition in news production or distribution.

Multiskilled journalists produce news for two or more media using the technological tools needed in every step of the process. In the case of Welt/Morgenpost, HNA and EI Mundo, journalists are encouraged to be multiskilled at the news-gathering level. However, multiskilling is not a precondition either in news production or in distribution. The percentage of multiskilled journalists at Österreich, La Verdad Multimedia and El Mundo is around 10 per cent; at Der Standard the percentage decreases to 5 per cent, at HNA it rises to 20 per cent and at Welt/Morgenpost it reaches 70 per cent.

Although journalists might share a great deal of journalistic values and practices, they do so under considerably disparate organizational structures (Meier, 2007, pp. 5-6), which are reflected in the layout of their newsrooms, so that work organization can be used as a paradigm for newsroom culture (Josephi, 1998, p. 169). In this area, the physical setting was first examined (Table 4). All of the media organizations had established their newsrooms in the same building, with the exception of Der Standard and La Verdad Multimedia, whose newsrooms are located in separate buildings.

Journalists' reaction to the implementation of newsroom convergence was also evaluated. According to Welt/Morgenpost's managing editor, there were "winners" and "losers" but the Internet was regarded as more of a journalistic opportunity for the individual journalist. At $H N A$, print and online journalists have the same work contracts and are paid at the same rate. Most print journalists at El Mundo are reluctant to embrace integration; most online journalists, however, are more inclined to do so.

With the exception of Der Standard, journalists do not get paid when working for another medium. Managers motivate journalists by appealing to personal success and to the professional reward of seeing their own work published in several media. Journalists seldom receive specific training for multiskilling. Only the two German media companies offered some courses for their staff. This means that most journalists have to learn new 
TABLE 4

Work organization

\begin{tabular}{|c|c|c|c|}
\hline & Full integration & Cross-media & $\begin{array}{l}\text { Co-ordination of } \\
\text { isolated platforms }\end{array}$ \\
\hline $\begin{array}{l}\text { Are newsrooms } \\
\text { located in one } \\
\text { building or in } \\
\text { separate buildings? }\end{array}$ & $\begin{array}{l}\text { Same building as } \\
\text { precondition }\end{array}$ & $\begin{array}{l}\text { Same building or at least } \\
\text { newsrooms within very } \\
\text { short walking distance }\end{array}$ & Not of importance \\
\hline $\begin{array}{l}\text { Are there separate } \\
\text { newsrooms or just } \\
\text { one? }\end{array}$ & One newsroom & $\begin{array}{l}\text { Separate newsrooms } \\
\text { with interconnections } \\
\text { (e.g. News desk) }\end{array}$ & Separate newsrooms \\
\hline $\begin{array}{l}\text { Journalists' attitude: } \\
\text { how do journalists } \\
\text { react to the } \\
\text { implementation of } \\
\text { newsroom } \\
\text { convergence? }\end{array}$ & $\begin{array}{l}\text { Ideal: they are well } \\
\text { prepared for the change } \\
\text { process which helps } \\
\text { with job satisfaction and } \\
\text { in seeing rather new } \\
\text { possibilities than risks } \\
\text { and threats of } \\
\text { extra work }\end{array}$ & $\begin{array}{l}\text { Many journalists are } \\
\text { hesitant about the idea of } \\
\text { implementation of one } \\
\text { single newsroom, } \\
\text { suspecting loss of } \\
\text { working quality and } \\
\text { individual hierarchical } \\
\text { positions }\end{array}$ & $\begin{array}{l}\text { Most journalists are } \\
\text { opposed to the } \\
\text { introduction of a } \\
\text { single newsroom }\end{array}$ \\
\hline $\begin{array}{l}\text { Does the number of } \\
\text { journalists change as } \\
\text { a result of } \\
\text { convergence? }\end{array}$ & $\begin{array}{l}\text { Full convergence is seen } \\
\text { as a possibility to } \\
\text { reduce staff, whereas in } \\
\text { practice there is a } \\
\text { change of qualifications } \\
\text { but not of number of } \\
\text { journalists }\end{array}$ & $\begin{array}{l}\text { Same number. There may } \\
\text { be an increase of the } \\
\text { necessary number of } \\
\text { high-profile journalists } \\
\text { with multimedia } \\
\text { experience }\end{array}$ & $\begin{array}{l}\text { Same number. Since } \\
\text { platform work is } \\
\text { isolated, journalists go } \\
\text { ahead with } \\
\text { production as } \\
\text { usual }\end{array}$ \\
\hline $\begin{array}{l}\text { Does the company } \\
\text { provide training in } \\
\text { multiskilling? }\end{array}$ & $\begin{array}{l}\text { Yes, continuously and } \\
\text { for all employees }\end{array}$ & $\begin{array}{l}\text { Yes, for some } \\
\text { employees }\end{array}$ & $\begin{array}{l}\text { Not especially. } \\
\text { Occasional } \\
\text { participation in } \\
\text { training programmes } \\
\text { is supported }\end{array}$ \\
\hline $\begin{array}{l}\text { Are multiskilled } \\
\text { journalists } \\
\text { compensated } \\
\text { economically, } \\
\text { or in any other way? }\end{array}$ & $\begin{array}{l}\text { No. But chances of } \\
\text { career advancement are } \\
\text { higher }\end{array}$ & No & No \\
\hline $\begin{array}{l}\text { Are new roles being } \\
\text { created as a result of } \\
\text { convergence } \\
\text { implementation? }\end{array}$ & $\begin{array}{l}\text { Yes, some. In } \\
\text { convergence } \\
\text { management as well as } \\
\text { new communication } \\
\text { contact points and team } \\
\text { leaders for editorial staff }\end{array}$ & $\begin{array}{l}\text { Yes, co-ordination } \\
\text { capacities for } \\
\text { cross-media activities }\end{array}$ & No \\
\hline $\begin{array}{l}\text { Is there a single } \\
\text { journalistic culture } \\
\text { or separate ones? }\end{array}$ & $\begin{array}{l}\text { One culture. The move } \\
\text { towards integration of } \\
\text { all sections and } \\
\text { platforms also } \\
\text { brings on a } \\
\text { common culture } \\
\text { of converged } \\
\text { media }\end{array}$ & $\begin{array}{l}\text { Separate cultures. } \\
\text { But the need for } \\
\text { co-operation and } \\
\text { communication } \\
\text { brings on some slow } \\
\text { exchange of } \\
\text { positions and } \\
\text { strategies }\end{array}$ & $\begin{array}{l}\text { Separate cultures. } \\
\text { Journalistic cultures } \\
\text { are kept strictly apart } \\
\text { in order to keep up } \\
\text { expertise in each field } \\
\text { without mixing up } \\
\text { methods and } \\
\text { practices }\end{array}$ \\
\hline
\end{tabular}

skills while they perform their news production tasks. Convergence has not involved a reduction of staff, with the exception of the Welt/Morgenpost print newsroom. On the other hand, El Mundo's online staff increased by 25 professionals in two years. Finally, there is no sign of an emerging "convergence culture", for each medium retains its own culture; 
there is, however, a gradual move towards a common culture in newsrooms such as $E I$ Mundo's, as print and online sections integrate.

\section{Three Different Models of Newsroom Convergence}

By analysing these areas, we aim to neutralize technological determinism and the usual industry mindset that states that full integration is the necessary final step of any convergence project. Few companies develop the four areas of convergence with similar intensity at the same time and most of them tend to pursue modest strategies that do not seem to greatly challenge established professional practices. Whereas in some cases newsroom redesign involves high technological standards and brings together journalists from all platforms in one common space, the editorial staff's approach towards convergence might still be reluctant, and company training programmes in multiskilling have hardly been implemented. Defining models like these will help structure in-depth analysis in each specific case and make it comparable with other cases.

Newsroom integration is therefore being developed in varying degrees of complexity. To sum up the results of the analysis, three different models of convergence may be outlined: full integration, cross-media and co-ordination of isolated platforms.

\section{Full Integration}

Architecture and infrastructure for multi-channel production are combined in one newsroom and controlled via a central news system with workflow management. Besides this characterization via external features, convergence is also a strategic goal. Production and distribution on different platforms is subordinated to news content production. "Online first" (Die Welt's slogan) has become a symbol for a paradigmatic shift from newspaper production towards multimedia production, even if it is not, as yet, as fully implemented as the research revealed. Full integration also means that training for all journalists is provided in order to ready them for multimedia production. Convergence of all platforms under the same ownership becomes the primary management goal.

None of the six case studies could be totally assigned to this model, although El Mundo and Die Welt/Berliner Morgenpost came closest to it. El Mundo's integration of print and Internet production and permanent co-operation within departments have been established step-by-step. In several sections, the full integration of Web and print with journalist's daily multimedia thinking and production is already considered normal. At Die Welt/Morgenpost, this process is also under way as even more elaborate content is produced for four newspapers (the three different editions of Welt and Morgenpost). For these companies in Madrid and Berlin, full convergence as a managerial aim has not yet been accomplished but preconditions have been established.

\section{Cross-media}

In this model, journalists work in separate newsrooms or sections for different platforms but are interconnected through multimedia co-ordinators and work routines. Cross-media collaboration refers to a process whereby more than one media platform is simultaneously engaged in communicating content. This does not necessarily happen in a completely integrated way. Usually, the production involves different kinds of co-operation. 
This may range from information sharing between journalists and desks on different platforms, through reporters producing content for more than one platform, to various forms of content reproduction for different platforms. In the more advanced models of integration and co-operation, the platforms serve different purposes to news coverage as a whole, implying a move towards the definition of a multiplatform concept.

Such a multiplatform concept would have an impact on editorial work and news flow between the platforms which is shown, for example, in the policy of "online first" not usually meant as a ranking in importance but as a time priority. In the cross-media model, management drives co-operation and communication in content production among the various media as well as cross-promotion. Journalists remain platform experts and multiskilling is the exception to the rule and is not actively fostered by management. Convergence is not considered a strategic need but a tool. Österreich, HNA and La Verdad Multimedia come closest to this model. At the latter, content is promoted cross-media: a multimedia manager and a news editor co-ordinate daily news production whereas journalists themselves only occasionally cross borders (e.g. as specialized print editors also analyse the main stories in television or radio news).

Österreich's model is an example of a cross-media concept, establishing a new newsroom architecture right from the outset but still having journalists working as platform specialists for print or online. Behind Österreich's strongly promoted multimedia concept, from its beginnings in 2006 until the present, there is an important technological and management concept which partly reflects the idea of "full convergence", but so far journalistic multiskilling is more the exception than the rule.

\section{Co-ordination of Isolated Platforms}

Co-operation is neither implemented systematically in news gathering nor in news production or news distribution. Journalism sections remain separate; newsroom design does not strive towards integration. Borders and differences between online, print, radio and television sections in the same media company do not seem surmountable and convergence is not even seen as an appropriate means of quality improvement. Cooperation in news production takes place - if at all — as a bottom-up process and more or less by chance, depending on individual journalists. Managers are not yet ready for-or interested in - organized cross-media strategies or convergent production, aggregation or distribution of news. Sometimes there is a co-ordination of single topics - e.g. with crosspromotions - and some journalists attend the editorial conferences of the "other" platform.

Der Standard in Vienna represents this model. Surprisingly, the autonomous model in this case appears to have been one of the success factors, as DerStandard.at has become the most visited website among Austria's online newspapers. It stands out as one of the very few examples of an originally print-based Internet company now making profits with its online edition. The system of isolated platforms might thus be regarded as a management weakness in creating cross-media co-operation as well as a strategy to give more time, space and continuity to the single platform, allowing it to concentrate on its success.

The isolation model does not appear to be forward-looking. The explosion of online and mobile news opportunities represents a new adventure for journalism. The "isolated platform" news philosophy is economically unsustainable in the long run since the mastering of processes along the value chain is much more difficult. Newsroom architecture, technology, management and journalism cultures that have been growing 
apart for years are now coming closer. As in the case of "Der Standard" with several years of "splendid platform isolation", one can foresee that times are changing and that audience needs must be addressed.

\section{Conclusions and Prospects}

None of these models exist, of course, in their "pure form", and no media company analysed is absolutely dedicated to full integration, cross-media collaboration or isolated newsrooms. Most convergence experiences can be attributed to one or other model as an idea, strategy or even philosophy, as our case studies have shown.

Nevertheless, we want to avoid oversimplifying the analysis: journalistic convergence should not be regarded as just an "effect" of corporate or technological trends. Technical innovation is usually based on professional and economic decisions and journalists adapt new tools to their own expectations, skills and routines. Therefore, journalistic convergence must be discussed not as a technology-driven process, but rather as a process that uses technological innovation to achieve specific goals in particular settings, and that is why each convergence project can reach a different outcome.

Since the discussion about convergence has now been going on for at least a decade, full integration has often been considered a valuable goal. However, many media managers in Austria, Germany and Spain agree that multimedia operations are buzzwords used at ease, whereas convergence is a multi-faceted and complex phenomenon. Looking deeper at journalistic production, we discovered that reality is still different from wishful thinking. Many countries face limits on cross-ownership, and this means limits on the extent of convergence. Yet there is still a great deal of partnering and collaboration with a variety of convergence strategies.

As a result of our research, we propose to rethink professional attitudes towards convergence. Newsroom layout is not the first thing to be considered, nor is convergence primarily about synergies. In all the models explored, news production for different channels is changing the conditions of newsroom organization and journalistic work. Even in the model of isolated platforms, the need for co-ordination and co-operation is growing. To fulfil these needs, media professionals have to learn to take into account the changing demands of audiences, the consequences for their news companies and the effects on their work.

The matrix we have developed may be helpful to restructure strategic considerations and to develop convergence concepts. Further research in other media companies, with different scopes and newsroom elements, will also help particularize and evaluate these models of newsroom convergence.

\section{ACKNOWLEDGEMENTS}

Subsidies from the Austrian Communications Authority (KommAustria) made it possible to conduct this research.

\section{NOTES}

1. Newsroom observation in each medium was conducted by two researchers from two different countries during a two-day period between November 2007 and February 2008. 
During each of those visits, open-ended interviews with at least two news managers and two journalists were held in each newsroom.

\section{REFERENCES}

BAUER, J. M. (2005) "Bundling, Differentiation, Alliances and Mergers: convergence strategies in U.S. communication markets", Communications \& Strategies 60(4), pp. 59-83.

BOCZKOWSKI, P. J. and FERRIS, J. A. (2005) "Multiple Media, Convergent Processes, and Divergent Products: organizational innovation in digital media production at a European firm", The Annals of the American Academy of Political and Social Science 597, pp. 32-47.

CHAN-OLMSTED, S. M. and CHANG, B. H. (2003) "Diversification Strategy of Global Media Conglomerates: examining its patterns and determinants", The Journal of Media Economics 16(4), pp. 213-33.

DAILEY, L., DEMO, L. and SPILLMAN, M. (2005) "The Convergence Continuum: a model for studying collaboration between media newsrooms", Atlantic Journal of Communication 13 , pp. $150-68$.

DEUZE, M. (2004) “What Is Multimedia Journalism?", Journalism Studies 5(2), pp. 139-52.

DUPAGNE, M. and GARRISON, B. (2006) "The Meaning and Influence of Convergence. A qualitative case study of newsroom work at the Tampa News Center", Journalism Studies 7, pp. 237-55.

ESSER, F. and PFETSCH, B. (Eds) (2004) Comparing Political Communication. Theories, cases and challenges, New York: Cambridge University Press.

GARCíA AVILÉS, J. A. (2006) El periodismo audiovisual ante la convergencia multimedia, Elche: Ed, Universidad Miguel Hernández.

GARCíA AVILÉS, J. A. and CARVAJAL, M. (2008) "Integrated and Cross-media Newsroom Convergence", Convergence 14(2), pp. 221-39.

HUANG, E., DAVISON, K., SHREVE, S., DAVIS, T., BETTENDORF, E. and NAIR, A. (2006) "Facing the Challenges of Media Convergence. Media professionals' concerns of working across media platforms", Convergence 12(1), pp. 83-98.

JOSEPHI, B. (1998) "The Influence of Newsroom Layout on News", Australian Studies in Journalism 7, pp. $164-76$.

KALTENBRUNNER, A., KARMASIN, M., KRAUS, D. and ZIMMERMANN, A. (2007) Der Journalisten-Report. Österreichs Medien und ihre Macher, Eine empirische Erhebung, Wien: facultas.

KILLEBREW, K. C. (2005) Managing Media Convergence, Ames, IA: Blackwell Publishing.

LAWSON-BORDERS, G. (2006) Media Organizations and Convergence. Case studies of media convergence pioneers, Mahwah, NJ: Lawrence Erlbaum.

MEIER, K. (2007) "Innovations in Central European Newsrooms: overview and case study", Journalism Practice 1(1), pp. 4-19.

MEIER, K. (2009) "Germany: Newsroom Innovations and Newsroom Convergence", in: Stephan Ruß-Mohl and Natascha Fioretti (Eds), Merging Media, Converging Newsrooms, Bellinzona, Switzerland: Casagrande.

MEYER, K. (2005) Crossmediale Kooperation von Print- und Online-Redaktionen bei Tageszeitungen in Deutschland, München: Herbert Utz Verlag.

NEUBERGER, C. and TONNEMACHER, J. (Eds) (2003) Online - Die Zukunft der Zeitung? Das Engagement deutscher Tageszeitungen im Internet, 2nd ed., Wiesbaden: Westdeutscher Verlag.

PAVLIK, J. V. (2004) "A Sea-change in Journalism: convergence, journalists, their audiences and sources", Convergence 10, pp. 21-9. 
QUINN, S. (2005) "Convergence's Fundamental Question", Journalism Studies 6(1), pp. 29-38.

SALTZIS, K. and DICKINSON, R. (2008) "Inside the Changing Newsroom: journalists' responses to media convergence", Aslib Proceedings 60(3), pp. 216-28.

SCHANTIN, D., JUUL, T. and MEIER, K. (2007) Cross-media Newsrooms in Germany, IFRA Special Report 07.2007, Darmstadt: IFRA.

SINGER, J. B. (2004) "Strange Bedfellows? The diffusion of convergence in four news organizations", Journalism Studies 5(1), pp. 3-18.

STAKE, R. (1995) The Art of Case Study Research, Newbury Park, CA: Sage.

STEINMAURER, T. (2002) Konzentriert und verflochten, Österreichs Mediensystem im Überblick, Wien and Innsbruck: Studienverlag.

Jose A. García Avilés (author to whom correspondence should be addressed), Universidad Miguel Hernández, Ed. Torreblanca, Avda de la Universidad, s/n 03202 Elche (Alicante), Spain. E-mail: jose.garciaa@umh.es

Klaus Meier, Hochschule Darmstadt, Campus Dieburg, Max-Planck-Str. 2, D-64807 Dieburg, Germany. E-mail: meier@h-da.de

Andy Kaltenbrunner, Medienhaus Wien, Alser Straße 22, 1090 Wien, Austria. E-mail: andy.kaltenbrunner@medianhaus-wein.at

Miguel Carvajal, Universidad Miguel Hernández, Ed. Torreblanca, Avda de la Universidad, s/n 03202 Elche (Alicante), Spain. E-mail: mcarvajal@umh.es

Daniela Kraus, Medienhaus Wien, Alser Straße 22, 1090 Wien, Austria. E-mail: daniela.kraus@medienhaus-wien.at 